\title{
The Odonata of Pohnpei, Eastern Caroline Islands, Micronesia
}

\author{
Dennis R. Paulson' \& Donald W. Buden ${ }^{2}$ \\ 'Slater Museum of Natural History, University of Puget Sound, \\ Tacoma, WA 98416 USA. Corresponding author <dpaulson@ups.edu> \\ ${ }^{2}$ Division of Natural Sciences and Mathematics, College of Micronesia-FSM, \\ P.O. Box 159, Kolonia, Pohnpei FM 96941. \\ <don_buden@comfsm.fm>
}

Received 27 April 2002; revised 13 June 2002; accepted 19 June 2002.

Key words: Odonata, dragonfly, Micronesia, Caroline Islands, Pohnpei, biogeography, speciation, Pacificothemis, Teinobasis.

\begin{abstract}
A collection of 448 Odonata specimens made on Pohnpei, Caroline Islands, Micronesia, in 2001-2002 allows a reassessment of the fauna of this small, isolated island. There are 15 species, including six species of the zygopteran genus Teinobasis, which apparently speciated in situ, an unusually great diversity for such a small island. One of these species was undescribed. A revised key to the Teinobasis of Pohnpei is included, the larvae of three species of Teinobasis are compared, and the females of $T$. aerides and Pacificothemis esakii are described for the first time. The three odonate species represented by adequate series, $T$. ariel, $T$. fortis, and Hemicordulia haluco, appear to increase in body size with elevation. The island still has all of its natural habitats, although native upland forests continue to decrease as more land is cleared for agriculture. All of the odonate species seem secure at this time, although $T$. nigrolutea appears to be less common now than in the past.
\end{abstract}

\section{Introduction}

Asahina (1940) recorded eight species of Odonata from Pohnpei, Eastern Caroline Islands, in a paper on the Anisoptera of Micronesia; he described two of the island's endemics, Hemicordulia haluco and Pacificothemis esakii, and reported six additional species that are widespread on the Asian and Australian mainland and on western Pacific islands. Lieftinck (1962) then monographed all the Odonata of Micronesia. He discussed 14 species from Pohnpei, separated the Agrionoptera of Pohnpei and Truk (= Chuuk) as a new species, $A$. sanguinolenta (recorded as A. insignis [Rambur] by Asahina 1940), and described five species of Teinobasis from Pohnpei. 


\section{The Island}

Pohnpei $\left(6^{\circ} 52^{\prime} \mathrm{N}, 158^{\circ} 13^{\prime} \mathrm{E}\right)$ is the highest $(772 \mathrm{~m})$ and largest $\left(355 \mathrm{~km}^{2}\right)$ of the Caroline Islands. It is the capital of the Federated States of Micronesia that includes also eight outlying (Pohnpei state) atolls and the islands of Yap, Chuuk (formerly Truk), and Kosrae states. Densely forested ridges and valleys radiate outward and downward from the rugged mountainous central highlands, where 11 peaks exceed $600 \mathrm{~m}$ in elevation (U.S. Army Corps of Engineers 1986).

During the period of this study, cloud forest, also known locally as dwarf or moss forest, occupied the highest peaks and ridges, usually above $600 \mathrm{~m}$. The trees were smaller in stature than at lower elevations and festooned with mosses, ferns, orchids, and other epiphytes, and the forest floor was rich in mosses and ferns. Wet seepage areas supported dense patches of the sedge Mapania pacifica, growing about $1 \mathrm{~m}$ high. Nearly pure stands of the high-elevation endemic Pandanus patina were scattered throughout the area. The flatter and better-drained summit regions had dense thickets that included several high-elevation endemic shrubs and trees. Tree ferns (Cyathea spp.) were common throughout. Merlin et al. (1992), based on MacLean et al. (1986), indicate that the total area of cloud forest on Pohnpei is only 1 ha, but this figure almost certainly is in error, and a revised estimate of 63 ha (Trustrum 1996) is doubtless more accurate.

Rainforest dominated by hardwood species such as Campnosperma brevipetiolata, Elaeocarpus carolinensis, Fragraea berteriana, and Parinari laurina covered much of the area between 200 and $600 \mathrm{~m}$. Palm forest was a subtype within this habitat and was dominated by the endemic kotop palm, Clinostigma ponapensis, which was especially numerous above $450 \mathrm{~m}$. The rainforest understory was generally open and dominated by young palms, ferns, and tree ferns. This zone has been reduced in recent years following increased cutting of forest patches for cultivation of sakau, Piper methysticum, the island's most important cash crop. Trustrum (1996) reported a decline in native upland forest from $42 \%$ of the total vegetation cover in 1975 to $15 \%$ in 1995 , due largely to this clearcutting of numerous 1-2 ha plots.

The lowlands (below about $200 \mathrm{~m}$ ) included native forest, grasslands, settlements, secondary woodland, agroforest (areas partially cleared for cultivation), marshes, and mangroves. Approximately 7,000 of the 31,540 people recorded during the 1994 FSM national census lived in Kolonia, the main settlement, the other people having been distributed among numerous small villages along the $87-\mathrm{km}$ circumferential road. No road traversed the island, and the central highlands were uninhabited.

Warm and humid conditions prevail year-round on Pohnpei. The average annual temperature is $27^{\circ} \mathrm{C}$ at sea level and $23^{\circ} \mathrm{C}$ at $450 \mathrm{~m}$ (Raynor 1993), and the average monthly temperature does not vary from the annual average by more than one degree (Laird 1982). Mean annual rainfall in Kolonia is approximately $485 \mathrm{~cm}$, with estimates for the central highlands varying from 750 to $1,015 \mathrm{~cm}$ (Merlin et al. 1992); these highlands are among the wettest places on Earth.

Aquatic habitats included (1) lowland ponds and marshes, some of them temporary; (2) highland marshes characteristic of flat areas on ridge tops and plateaus; (3) streams and rivers; and (4) phytotelmata (leaf axils of Freycinetia and other plants). Two of these habitats are shown in Figure 1. 


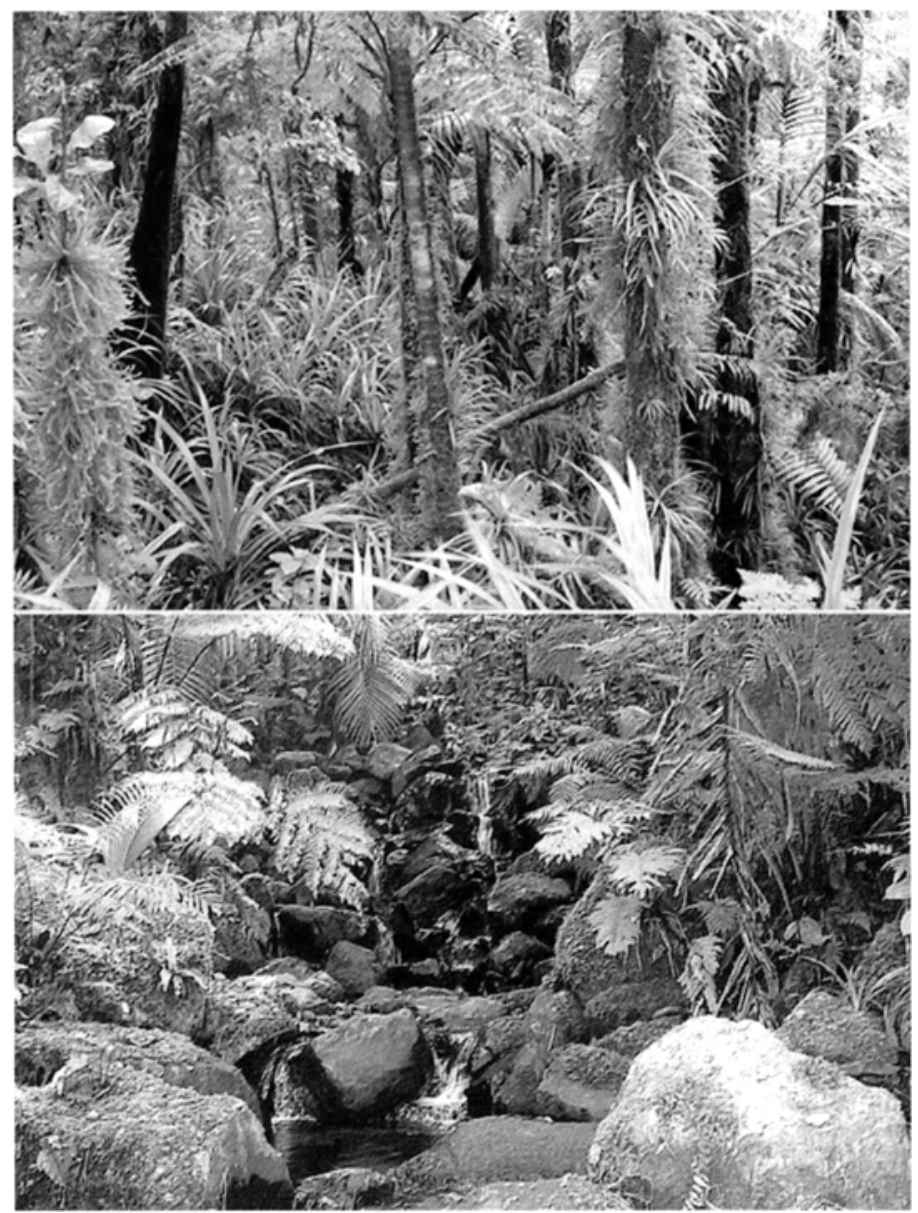

Figure 1. Cloud forest on Nahnalaud (above) and Lehn Mesi River headwaters (below).

\section{Methods}

Adult Odonata were collected opportunistically and intermittently during February 2001-January 2002; the collection totaled 448 specimens. The more remote highlands areas - the least accessible parts of the island - were reached by backpacking for 2-4 days at a time: 15-16 March; 12-13 May; 12-13, 17-19, and 28-29 June; 10-13 and 24-27 July; 2-4 August; 2-3 November; 24-26 December; and 1-4 January. Lower elevations were sampled during shorter visits of from one to several hours over a total of 40 days in February (2 days), April (4), May (1), June (3), July (8), August (3), September (8), October (5), November (2), December (3), and January (1). Collecting was most intense from June through December (Table 1), and the low figures for species in some months are very likely indicative of nothing more than low effort during those months. These data can serve as a base line for further assessments of seasonality. 
Table 1. Seasonal representation of Pohnpei Odonata; for each month of collection the number of specimens is given; L: literature record.

\begin{tabular}{|c|c|c|c|c|c|c|c|c|c|c|c|c|c|}
\hline & I & II & III & IV & $\mathrm{V}$ & VI & VII & VIII & IX & $\mathrm{X}$ & $\mathrm{XI}$ & XII & Total \\
\hline $\begin{array}{l}\text { Ischnura } \\
\text { aurora }\end{array}$ & $\mathrm{L}$ & $\mathrm{L}$ & L & - & - & $\mathbf{L}$ & 6 & - & 6 & 9 & - & - & 21 \\
\hline $\begin{array}{l}\text { Teinobasis } \\
\text { aerides }\end{array}$ & 4 & - & 2 & - & - & 1 & 5 & 1 & - & - & 1 & 1 & 15 \\
\hline T. ariel & 9 & 2 & 1 & - & 1 & 16 & 19 & 25 & 5 & 2 & 14 & 22 & 116 \\
\hline T. budeni & - & 1 & - & - & - & 3 & 2 & - & 2 & 3 & - & - & 11 \\
\hline T. fortis & 3 & 4 & - & - & - & 6 & 22 & 10 & 45 & 11 & 16 & 16 & 133 \\
\hline T. nigrolutea & 4 & - & - & - & - & 3 & - & - & 1 & - & - & 1 & 9 \\
\hline$T$. ponapensis & 2 & - & - & - & - & 1 & - & - & - & - & - & - & 3 \\
\hline Anax guttatus & L & - & - & 2 & - & & $\mathrm{L}$ & 1 & - & - & $\mathbf{L}$ & 1 & 4 \\
\hline $\begin{array}{l}\text { Hemicordulia } \\
\text { haluco }\end{array}$ & 3 & $\mathrm{~L}$ & - & 6 & 4 & 18 & 4 & 1 & 3 & 1 & 7 & 1 & 48 \\
\hline $\begin{array}{l}\text { Agrionoptera } \\
\text { sanguinolenta }\end{array}$ & L & $\mathrm{L}$ & - & 1 & 2 & 3 & 2 & $\mathrm{~L}$ & 4 & 7 & 1 & - & 20 \\
\hline $\begin{array}{l}\text { Diplacodes } \\
\text { bipunctata }\end{array}$ & 4 & 3 & - & $\mathrm{L}$ & - & 12 & 2 & L & 1 & 4 & $\mathrm{~L}$ & 8 & 34 \\
\hline $\begin{array}{l}\text { Pacificothemis } \\
\text { esakii }\end{array}$ & 2 & - & - & - & - & & 1 & 3 & - & - & 3 & - & 9 \\
\hline $\begin{array}{l}\text { Pantala } \\
\text { flavescens }\end{array}$ & L & - & - & - & - & 5 & 5 & - & - & 2 & 1 & - & 13 \\
\hline $\begin{array}{l}\text { Tholymis } \\
\text { tillarga }\end{array}$ & L & - & - & - & - & 3 & 3 & - & - & 1 & L & - & 7 \\
\hline $\begin{array}{l}\text { Tramea } \\
\text { transmarina }\end{array}$ & $\mathrm{L}$ & - & - & - & - & 1 & 1 & $\mathrm{~L}$ & 1 & 1 & 1 & - & 5 \\
\hline Total species & 14 & 7 & 3 & 4 & 3 & 13 & 13 & 9 & 9 & 10 & 11 & 7 & \\
\hline $\begin{array}{l}\text { Total } \\
\text { specimens }\end{array}$ & 31 & 10 & 3 & 9 & 7 & 72 & 72 & 41 & 68 & 41 & 44 & 50 & \\
\hline
\end{tabular}

The amount of time spent in each major habitat or elevation zone (lowlands, midto-upper-level rainforest, cloud forest) was roughly proportional to its contribution to 
the total area of the island, with the exception of a disproportionately greater amount of time spent in the cloud forest, which is limited to the highest peaks and ridges. Odonate surveys in mangroves were done jointly with census studies (point counts) of pigeons and doves and completed over a period of 6 days on four different transects covering a total of $3.8 \mathrm{~km}$.

The number of specimens collected of each species provides a crude measure of relative abundance, but the most common species are underrepresented, as their collections were often curtailed to cover more area and increase the likelihood of encountering the rarer species. Large anisopterans are more difficult to collect than small anisopterans and zygopterans and are thus disproportionately less common in the collections relative to their abundance in Pohnpei.

Unfortunately, no attempts could be made to determine breeding habitats through larval collections, but a few emerging Teinobasis found at the waterside are indicative of breeding habitat, and exuviae of two species of libellulids were found. Teneral Teinobasis were also collected regularly to furnish information about breeding sites.

Place names are largely from the most recently issued topographic map of Pohnpei (U.S. Geological Survey 1983). Numerous local alternative spellings have been used for many localities in the past, and our selection among these has been somewhat arbitrary but with an attempt to be consistent with those most often used in previous biological publications. Recorded distances are based on straight-line measurements on the topographic map, and elevations were measured with a Barigo altimeter scaled in 20-foot increments; some elevations were taken in meters from known locations. Elevations were then all converted to meters. Figure 2 shows the municipalities and river systems of the island, as well as the mangrove forests and highest elevations.

After each species name, the municipality from which specimens were collected are listed (in counterclockwise order around the island) along with the known elevation range, as a general indication of where the species is known to occur, followed by the number of specimens preserved. The specific localities and dates of specimens are available from the authors. We think that most if not all species occur island-wide in their appropriate habitats and elevation ranges.

The published record contributes relatively little to the knowledge of size variation in Micronesian Odonata, so we include measurements of all species in Table 2.

The authorities of all Micronesian Odonata names are given in Table 4.

\section{The Pohnpei species}

\section{ZYGOPTERA}

\section{Coenagrionidae}

\section{Ischnura aurora (Brauer)}

Kolonia, Sokehs, Madolenihmw, $30 \mathrm{~m} ; 11 \precsim$, 10 ․ Eye colors in life black above, pale green below in both sexes. This species was encountered at only four localities (none 


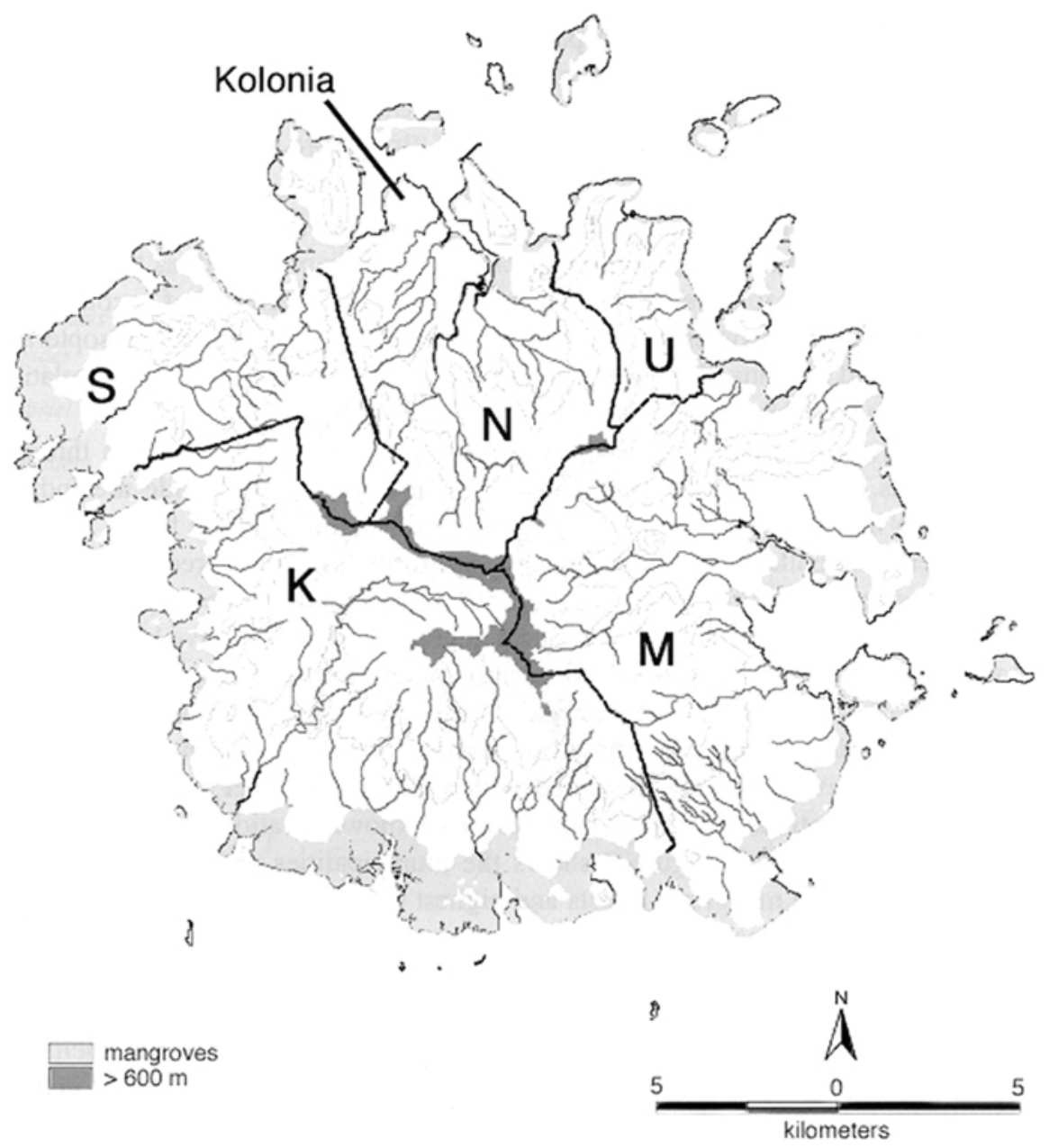

Figure 2. Map of Pohnpei with rivers and municipalities. K: Kitti, M: Madolenihmw, N: Nett, S: Sokehs, U: U.

above $30 \mathrm{~m}$ ), in wet grassy, weedy areas and a flooded taro patch. It is probably common to locally very common in the lowlands. I. aurora is very widespread in the Southwest Pacific, with high powers of dispersal, particularly in immature females (Rowe 1978).

The genus Teinobasis: The members of this genus on Pohnpei fall into two seemingly natural groups: (1) the Ariel-group, with aerides and ariel, characterized by dull coloration: thorax bronze and gray, faint if any pruinosity, eyes not blue; and (2) the Fortis-group, with fortis, nigrolutea, ponapensis, and budeni, characterized by bright coloration: thorax metallic blue and yellow in immature, pruinosity at maturity in all but nigrolutea, eyes at least partially blue. Although Lieftinck (1962) defined T. nigrolutea 
Table 2. Measurements of Pohnpei Odonata; abdomen length includes anal appendages.

\begin{tabular}{|c|c|c|c|c|c|c|c|}
\hline & \multirow[t]{2}{*}{ Sex } & \multicolumn{3}{|c|}{ Hindwing } & \multicolumn{3}{|c|}{ Abdomen } \\
\hline & & Mean & Range & $n$ & Mean & Range & $n$ \\
\hline \multirow[t]{2}{*}{ Ischnura aurora } & $\sigma$ & 10.8 & $10.5-11.5$ & 8 & 17.8 & $17.5-19$ & 5 \\
\hline & $q$ & 12.4 & $11.5-13.5$ & 10 & 18.2 & $17-19.5$ & 9 \\
\hline \multirow[t]{2}{*}{ Teinobasis aerides } & o & 22.1 & $21-23$ & 7 & 38.8 & $38-41$ & 6 \\
\hline & q & 22.4 & $21.5-23$ & 8 & 35.6 & $34.5-37$ & 8 \\
\hline \multirow[t]{2}{*}{ T. ariel } & $\delta$ & 19.3 & $16-22$ & 94 & 31.5 & $26-35.5$ & 66 \\
\hline & $q$ & 20.2 & $18.5-22$ & 16 & 30.3 & $28-31.5$ & 12 \\
\hline \multirow[t]{2}{*}{ T. budeni } & $\delta$ & 20.1 & $20-21$ & 8 & 30.3 & $30-31$ & 5 \\
\hline & $q$ & 20.5 & $20-21$ & 2 & 28.5 & $28-29$ & 2 \\
\hline \multirow[t]{2}{*}{ T. fortis } & $\delta$ & 21.9 & $20-24$ & 82 & 32.4 & $29-34$ & 47 \\
\hline & q & 22.8 & $21-24$ & 38 & 31.1 & $30-33$ & 20 \\
\hline \multirow[t]{2}{*}{ T. nigrolutea } & $\sigma$ & 20.6 & $20-21.5$ & 4 & 30.6 & $29.5-32.5$ & 4 \\
\hline & $q$ & 21.3 & $20.5-22.5$ & 5 & 28.5 & $26-30.5$ & 4 \\
\hline T. ponapensis & $\delta$ & 21.0 & 21 & 3 & 31.3 & $31-31.5$ & 3 \\
\hline \multirow[t]{2}{*}{ Anax guttatus } & $\delta$ & 52.7 & $51-55$ & 3 & 59.3 & $59-60$ & 3 \\
\hline & $q$ & - & 51 & 1 & - & 54 & 1 \\
\hline \multirow[t]{2}{*}{ Hemicordulia haluco } & $\delta$ & 28.2 & $27-29.5$ & 37 & 32.6 & $30-35$ & 18 \\
\hline & $q$ & 29.9 & $29.5-31.5$ & 11 & 36.4 & $36-37$ & 6 \\
\hline \multirow[t]{2}{*}{ Agrionoptera sanguinolenta } & $\sigma$ & 25.1 & $23.5-26$ & 11 & 23.8 & $21.5-26$ & 8 \\
\hline & q & 27.0 & $25.5-28.5$ & 9 & 25.6 & $25-27$ & 4 \\
\hline \multirow[t]{2}{*}{ Diplacodes bipunctata } & $\delta$ & 20.0 & $18.5-22.5$ & 14 & 18.7 & $16-20$ & 13 \\
\hline & $q$ & 19.8 & $18.5-21$ & 19 & 18.6 & $17-20$ & 10 \\
\hline \multirow[t]{2}{*}{ Pacificothemis esakii } & $\delta$ & 24.6 & $23.5-25$ & 5 & 21.5 & $20.5-22$ & 3 \\
\hline & $q$ & 24.8 & $24-25$ & 4 & 21.9 & $21-23$ & 4 \\
\hline \multirow[t]{2}{*}{ Pantala flavescens } & $\sigma^{2}$ & 40.0 & $36.5-42$ & 10 & 31.6 & $29-34$ & 7 \\
\hline & $q$ & 40.3 & $39-41.5$ & 2 & 33.5 & $32-35$ & 2 \\
\hline \multirow[t]{2}{*}{ Tholymis tillarga } & $\sigma$ & 32.8 & $32-34$ & 6 & 27.8 & $27-29$ & 6 \\
\hline & $q$ & - & 31 & 1 & - & 25 & 1 \\
\hline \multirow[t]{2}{*}{ Tramea transmarina } & $\sigma^{*}$ & 44.5 & $44.5-44.5$ & 2 & 34.5 & $34-35$ & 3 \\
\hline & 우 & - & 45 & 1 & - & 34.5 & 1 \\
\hline
\end{tabular}

by its vivid blue-black and yellow color, immatures of all species of the Fortis-group share that coloration (strong supposition for T. ponapensis). We have not found structural differences between the two groups. In fact, the anal appendages are very similar in all 
species, quite uniform in comparison with the range of variation in Teinobasis in other parts of its range (Needham \& Gyger 1939; Lieftinck 1962). Females do not seem to be separable based on thoracic characters, unlike those of most coenagrionid genera, but the structure of the ovipositor is distinctive for each species (Fig. 3).

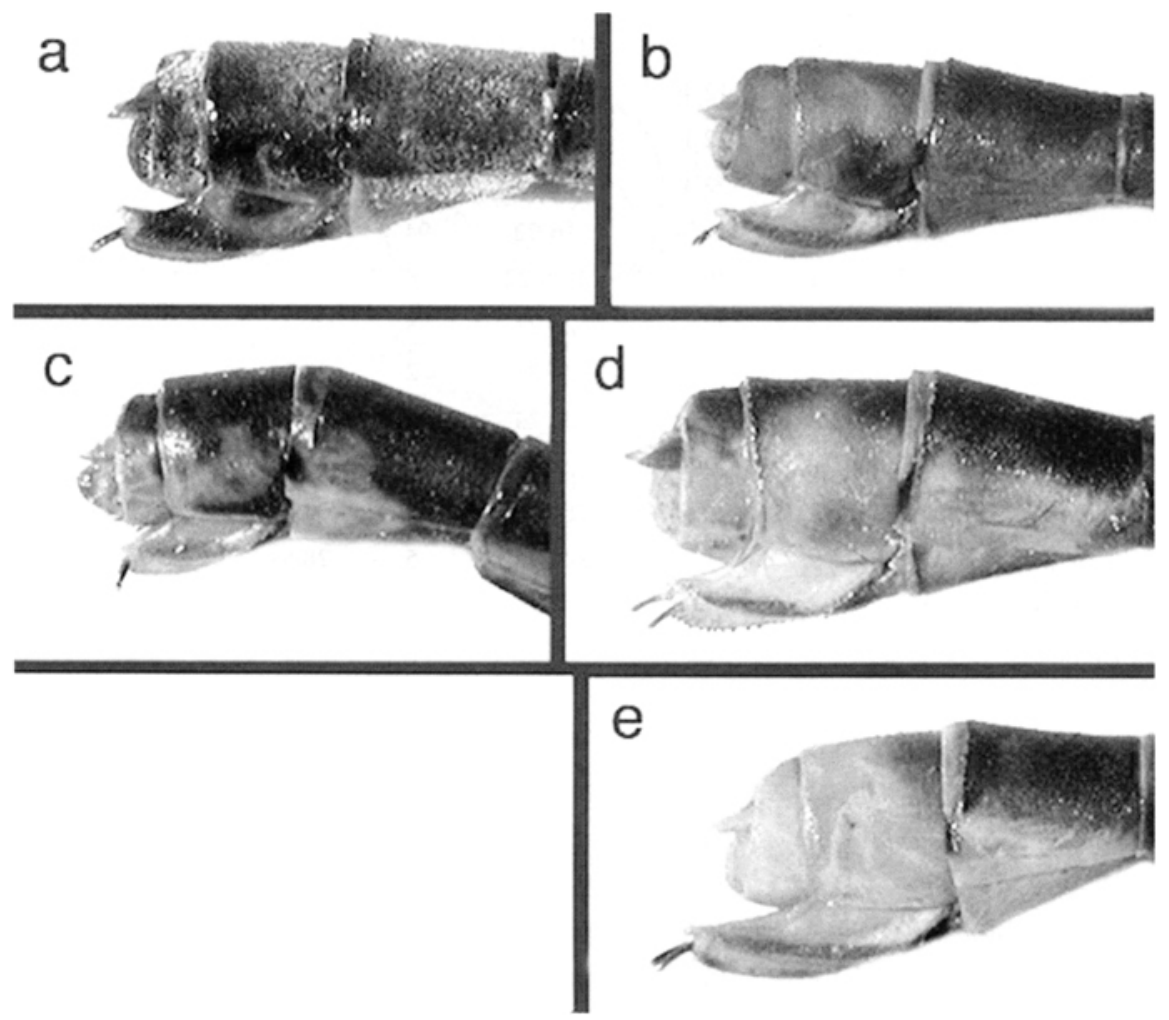

Figure 3. Terminal abdominal segments of female Teinobasis; all at same scale - (a) fortis, (b) ariel, (c) budeni, (d) aerides, (e) nigrolutea.

The key in Lieftinck (1962) will not suffice to identify females of three species for which that sex was unknown at that time. It is also inadequate for immatures, some of which are colored like adult $T$. nigrolutea. Also, $T$. fortis was distinguished by divided cells between the costa and radius distal to the pterostigma, but in a small proportion of individuals of that species, there are no divided cells. We therefore present a revised key to Teinobasis species (female ponapensis still unknown).

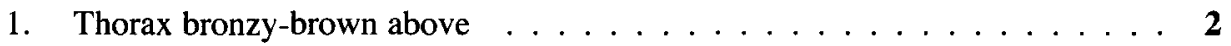

1'. Thorax metallic blue-black above ................ 3 
2. Larger (abdomen $>37 \mathrm{~mm}$ in $\delta,>34 \mathrm{~mm}$ in $\phi$ ); fine pale line at mesopleural suture does not reach upper end of suture and extends less than halfway down it; labrum largely pale; Pt pale; teeth on ovipositor coarse $(<12)$ and slightly irregularly spaced, ovipositor valves straight for most of length . . . . . . . . . aerides

2'. Smaller (abdomen $<36 \mathrm{~mm}$ in $\delta^{\star},<32 \mathrm{~mm}$ in + ); fine pale line at mesopleural suture begins at upper end of mesepimeron and extends about halfway down the suture; labrum black; Pt usually black (brown in some individuals); teeth on ovipositor fine (>15) and evenly spaced, ovipositor valves slightly but smoothly curved for entire length

ariel

3. Typically $\geq 7$ cells between $\mathbf{C}$ and $\mathrm{R}_{1}$ distal to $\mathrm{Pt}$; inferior dorsoapical process of male S10 deeply emarginate, its branches produced to form a pair of strongly recurved hooks ...................... fortis

3'. Typically $\leq 6$ cells between $\mathrm{C}$ and $\mathrm{R}_{\text {, }}$ distal to Pt; process of $\mathrm{S} 10$ much less extended

4. Pt rectangular, front and rear conspicuously longer than sides; $\delta$ with lower branch of cercus reaching $>50 \%$ of upper branch; ovipositor valves extend beyond tips of cerci nigrolutea

4'. Pt rhomboid, little difference in length between front/rear and sides; $\delta$ with lower branch of cercus not reaching $50 \%$ of upper branch; ovipositor valves do not extend to tips of cerci

5. $\delta$ with lower branch of cercus very short, not visible in side view; process of S10 extended as a horizontal shelf; posterior lobe of prothorax elevated almost at right angles to median lobe; labrum pale anteriorly . . . . . . . . . . . budeni

5 . $\delta$ with lower branch of cercus reaching about $40 \%$ length of upper branch; no shelflike process of S10; posterior lobe of prothorax not elevated; labrum black

ponapensis

Although Lieftinck (1962) distinguished T. nigrolutea from the other Teinobasis by its striking black and yellow/orange color pattern, immatures of all species of the Fortis-group are similarly colored. The three species for which this age stage is known can be distinguished by both color and morphology. In T. fortis, the black of the mesothorax is more restricted, not reaching the metapleural suture at its upper end, and $S 1$ is yellow with about the posterior third black dorsally. In T. nigrolutea, the black mesothorax is sharply delineated from the yellow metathorax, and S1 is almost all yellow, only narrowly black posterodorsally. In budeni, the black of the mesothorax extends onto the metathorax at its upper end, crossing the metapleural suture, and S1 is almost entirely black dorsally. In addition, the three species can be distinguished by male appendages and female ovipositor length: longest in nigrolutea, intermediate in fortis, shortest in budeni (Fig. 3). Immature coloration of $T$. ponapensis remains to be discovered.

Lieftinck (1962: fig. 9) described and illustrated a Teinobasis larva thought to be either $T$. ariel or $T$. nigrolutea. DWB collected one $T$. ariel and two $T$. fortis at emer- 
gence, and examination of the exuviae of these specimens shows that both differ from the larva illustrated by Lieftinck. The exuvia of T. ariel (Fig. 4) is much like Lieftinck's larva, with three palpal and one pair of premental setae and similar antennae. However, the labium is slightly narrower $-2.3 \times 1.9 \mathrm{~mm}$ in the exuvia, that of the larva almost as wide as long - , and the labial palpi are distinctly broader at the tip, the terminal spine conspicuously longer. Unless there is much individual variation in this character, the two appear to be different. $T$. fortis is quite different, with a huge, almost grotesque labium slightly wider than the width of the head and almost parallel-sided (Fig. 4); it measures $3.5 \times 3.4 \mathrm{~mm}$ in one exuvia. There are four palpal setae on both exuviae and no apparent premental setae. The head is parallel-sided, the eyes not as prominent as they are in ariel and Lieftinck's larva. The hooks on the labial palpi are very large and much more strongly curved than those of ariel or Lieftinck's larva, although the shape of the tip of the palpus is much like that of Lieftinck's larva. Antennal segment 4 is considerably longer than S2, about the same length in the other two. Finally, the caudal lamellae of fortis are much narrower than those of Lieftinck's larva, the laterals the same shape as the median and all with attenuate tips; a lateral lamella on one exuvia measures $5.2 \times 1.9 \mathrm{~mm}$. The ariel exuvia lacks lamellae. Because of the leaf-axil source of Lieftinck's larva, we suspect it is nigrolutea. Because of this, we consider Polhemus et al. (2000) in error in stating that $T$. ariel "is known to breed in the leaf axils of Freycinetia in a manner similar to several Megalagrion species in Hawaii." Similarly, it appears that Lieftinck's (1962) statement, with regard to Pohnpei Teinobasis, that "probably all of these forest dwellers have arboreal habits ..." was premature.

\section{Teinobasis aerides Lieftinck}

Nett, Sokehs, Kitti, Madolenihmw, 274-772 m; $7 \precsim, 8$ \%. Eye colors in life black above, pale green below in both sexes. This species appears confined to higher-elevation forested areas, being most numerous, but nowhere common, in cloud forest sites in seepage areas dominated by the sedge Mapania pacifica. It seems likely that it breeds in these habitats, along with the smaller and more common $T$. ariel. However, the most immature specimen (just post-teneral) was found in streamside vegetation. Of the 15 specimens collected during the study period, $11(73 \%)$ were above $600 \mathrm{~m}$. The species was described from a single male from Mt. Pairot, $660 \mathrm{~m}$. The name Pairot does not appear on any modern maps and is unknown to the many resident Pohnpeians who were queried, but the coordinates for Pairot $\left(6^{\circ} 58^{\prime} \mathrm{N}, 158^{\circ} 11^{\prime} \mathrm{E}\right)$ in Gressitt (1954: 229) are very near those for Pekenuht $\left(6^{\circ} 53^{\prime} \mathrm{N}, 158^{\circ} 12^{\prime} \mathrm{E}\right)$ as reported by Bryan (1971). The female, not previously described, is superficially like that of $T$. ariel but is larger (Table 2) and differs in both coloration and morphology (see the key to Teinobasis species for differences).

\section{Teinobasis ariel Lieftinck}

Nett, Sokehs, Kitti, Madolenihmw, U, 76-762 m; 99 б, 17 q. Eye colors in life black in both sexes; immature male olive above, pale green below. This species appears to be the most ubiquitous odonate on Pohnpei, occurring throughout the elevation range of the island and occupying a wide variety of habitats. Our specimens were taken as low as $76 \mathrm{~m}$, the lowest stream surveyed, and Lieftinck (1962) reported the species from Kolonia and Sokehs Island, near sea level. It was not only abundant along fast-flowing 


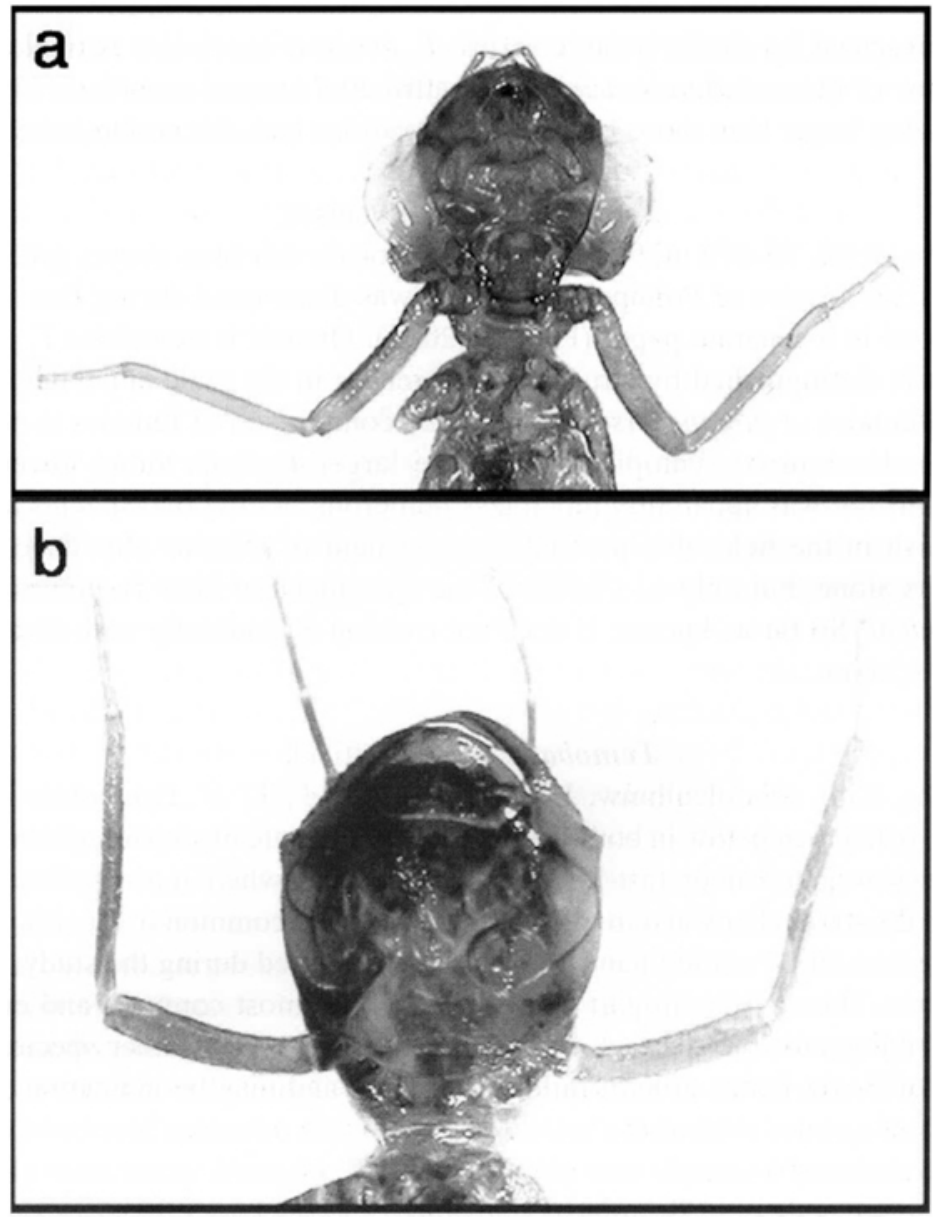

Figure 4. Ventral view of head of exuviae of Teinobasis ariel and T. fortis; both at same scale - (a) ariel, (b) fortis.

rocky streams throughout the forest zone (with $T$. fortis) but also common in Mapania sedge marshes at high elevation (with $T$. aerides). Although tenerals were found at both of these rather different environments (one with its exuvia at the foot of Pahn Takai Falls), it is not clear which, if either, is preferred breeding habitat. The other Teinobasis species all seemed to prefer one or the other of these habitats. On the streams, adult ariel showed a predilection for streamside vegetation rather than rocks. They were also frequently encountered in forest understory well away from water. We consider it peculiar that only a single mating pair of this species was collected, in a cloud-forest thicket, in comparison with $T$. fortis, in which pairs were seen commonly ( 27 were collected) over rivers. Perhaps $T$. ariel mates away from the water, but, just as peculiar, no ovipositing pairs or females were recorded. $T$. ariel is surprisingly variable in size, male hindwing length varying from $16-22 \mathrm{~mm}$, abdomen length from $26-35.5 \mathrm{~mm}$ (Table 2). The only other 
species represented by similarly large series, $T$. fortis, is much less variable (Table 2). At least some of the variation in ariel can be attributed to specimens from higher elevations averaging larger than those from lower elevations (see discussion below).

Teinobasis budeni Paulson

Nett, Sokehs, Kitti, 76-472 m; 9 t, 2 \&. Eye colors in life blue above, green below in female. A sixth species of Pohnpei Teinobasis was discovered during this survey, and it is described in a separate paper (Paulson 2003). Overall it resembles $T$. ponapensis exactly but is distinguished by structural differences in the male appendages and prothorax; no females of ponapensis are known, so comparison of females is not possible at this time. It occurred syntopically with the larger $T$. fortis along lower-elevation rocky streams but was apparently much less numerous. As the two species are difficult to distinguish in the field, this precludes assessment of relative abundance based on observations alone, but only $11(7.4 \%)$ of the specimens of blue Teinobasis collected were of budeni. So far as known, it does not overlap altitudinally with $T$. ponapensis, a highland species.

\section{Teinobasis fortis Lieftinck}

Nett, Sokehs, Kitti, Madolenihmw, U, 46-585 m; 86 ऽ, 47 ㅇ. Eye colors in life dark blue above, pale green below in both sexes, immature female black with green highlights. This species was abundant on fast-flowing rocky streams, where it most often perched on rocks along the stream bank and in midstream. Pairs were common ovipositing in tandem in these streams. Of 28 mating pairs of Teinobasis captured during the study, all but one were T. fortis. This may be in part because it was the most common and conspicuous member of the genus, but the lack of encounters with pairs of other species, except a single pair of $T$. ariel, was at least mildly surprising and may be indicative of different habits.

\section{Teinobasis nigrolutea Lieftinck}

Sokehs, Kitti, Madolenihmw, 152-650 m; 4 o, 5 ㅇ. Eye colors in life dark blue above, paler blue below in female. This species was encountered occasionally in wet forest at a wide range of elevations. It was syntopic with all the other species of Teinobasis, but its breeding habitat is not certain. Lieftinck (1962) described a Teinobasis larva from the leaf axil of Freycinetia, so we assume at least one species of the genus breeds in phytotelmata, and it is likely that it is $T$. nigrolutea, as we think all the other species breed in streams and/or marshes. The distinctive elongate ovipositor of nigrolutea points to a distinctive oviposition substrate, if not a distinctive habitat choice. None of the specimens of nigrolutea collected during this study was fully mature, and the youngest individuals were found in forest both near aquatic habitats and away from them. Oddly, Lieftinck (1962) made no mention of immaturity in the 11 specimens he examined.

\section{Teinobasis ponapensis Lieftinck}

Madolenihmw, 606-655 m; 3 ठ. This species was taken only near moss- and fern-covered rocks at streams in rain/cloud forest transition on Ngihneni and nearby Dolohmwar. Both $T$. ariel and $T$. fortis occurred at the same locations. $T$. ponapensis was described 
from a single male taken on Ngihneni at 730 meters elevation, so it may be a species limited to the highlands and presumably breeds in streams. It remains to be seen how extensive its range is at these elevations.

\section{ANISOPTERA}

\section{AeshnidaE}

\section{Anax guttatus (Burmeister)}

Sokehs, $90 \mathrm{~m} ; 3 \delta, 1$. Eye colors in life green in male. This species was rare to uncommon but more numerous than the scanty records indicate. It often flew low, 1-3 m above the ground, but was extremely evasive and frequently eluded capture. It was most likely to be encountered in sparsely vegetated open areas, and it occasionally entered open doorways and windows of buildings.

\section{CORDUlitida}

\section{Hemicordulia haluco Asahina}

Nett, Sokehs, Kitti, Madolenihmw, 1-772 m; $37 \delta, 11$. Eye colors in life green in both sexes, immature female brown above, green below. This species was common in open grassy areas and fern brakes throughout, from lowlands to the highest mountains; one was collected in a small grassy patch (ca $\left.3.5 \mathrm{~m}^{2}\right)$ surrounded by cloud forest vegetation on the summit of Nahnalaud at $772 \mathrm{~m}$. This was the most widespread and one of the most common dragonfly species on Pohnpei. It was usually observed in flight just above the ground cover. It usually patrolled a relatively small area, often in a roughly circular pattern two to several meters in diameter. These were presumably feeding flights, as they were usually seen away from the water. The only one observed perched was aligned vertically at the tip of a small branch. $H$. haluco was most numerous in the grasslands just SSW of the animal farm (piggery) at Pohnpei Agriculture and Trade School, but it was also encountered regularly in many open grassy and shrubby areas along cloudforest ridges between Nahnalaud and Ngihneni. It had a predilection for areas exposed to the sun at all elevations and was absent from beneath intervening forest canopy. Although common, with immature individuals frequently seen, its breeding habitat was not determined. It seems unlikely to be forest streams, as individuals were never seen over them. Other species of Hemicordulia breed in both ponds and streams (D.R. Paulson pers. obs.).

\section{LIBELLULIDAE}

\section{Agrionoptera sanguinolenta Lieftinck}

Kolonia, Nett, Sokehs, Kitti, Madolenihmw, 0-653 m; 11 o, 9 \%. Eye colors in life brown to reddish brown to violet above, greenish to yellow below in both sexes. This species was fairly common in grassy, weedy areas with scattered shrubs and small trees, often at the forest edge. It was often encountered on exposed perches, including branches of small trees and shrubs and tall emergent grass blades. It was usually wary and seldom 
allowed close approach. When disturbed, it would fly to another perch a short distance away and would relocate to several adjacent perches when pursued before eventually disappearing from view. It presumably breeds in swampy wetlands like other members of the genus (D.R. Paulson pers. obs.), but neither breeding activity nor emergence was noted.

\section{Diplacodes bipunctata (Brauer)}

Kolonia, Nett, Kitti, Madolenihmw, U, 30-475 m; 15 o, $19 \%$. This species was common in open, sparsely vegetated areas throughout the lowlands. It was the most common odonate at a salt marsh at Nan Panilap on 27 December (8 collected), and two Agrionoptera sanguinolenta and one Pantala flavescens were the only other odonates observed; this marsh was fresher on previous visits. It usually flew only a few centimeters above the ground, then perched on the vegetation and ground, typically cocking its wings slightly forward upon landing. It was especially numerous at rain-filled potholes in unpaved roadway at the Pohnpei Agriculture and Trade School, where many pairs were observed flying in tandem in June. It was also very common along the sparsely vegetated causeway between Takaieu Island and mainland Pohnpei, where 54 were counted in 20 min over a distance of $1 \mathrm{~km}$ on 1 September. An exuvia was collected from a small fountain in Kolonia on 30 December, where it emerged with the more numerous Tholymis tillarga.

\section{Pacificothemis esakii Asahina}

Nett, Sokehs, Kitti, Madolenihmw, 46-655 m; 5 $\delta, 4$ 오. Eye colors in life green (or blackish above, green below) in male, brown to orange-brown above, green below in female. This species was uncommon but fairly widespread and occurred throughout the elevation range of the island. Specimens were taken along streams and over an open fern brake, a marshy slope, and a sakau plantation. All nine were perched - mainly horizontally, but some at angles - on vegetation, including grasses, sedges, shrubs and small trees. None was observed making sustained flights except to avoid capture, and usually after being pursued and flushed from several different perches. The type male was collected at Ronkiti-One (= Ronkiti-Wone) in the lowlands of southern Pohnpei between the settlements of Ronkiti and Wone, July 1939 (Asahina 1940), and three males were collected in Kolonia during June-September 1950 (Lieftinck 1962). Tenerals were collected along the Nanpil River at low elevation and in open areas near both streams and marshes at higher elevation, so we are uncertain about its breeding habitat. However, two females carrying eggs were collected along streams in the lowlands, so streams seem the likely habitat. The female of this species has not been described. It is superficially much like the male but with thicker abdomen, as expected. The vulvar lamina is scarcely developed and very shallowly notched. Color pattern of the head and thorax is identical to that of the male, but mature females retain a patterned abdomen, as follows. The abdomen is entirely black except S1-3 are mostly orange, with black lines along the carinae and the posterior fifth of S3 black. There are orange dorsomedial spots on either side of S4-8, the spots occupying the anterior third and upper half of the segment and just touching at the midline. In teneral females, the orange is slightly more extensive, while in teneral males, the pattern is very much like that of mature females. In mature males, the abdomen becomes entirely black, with only a hint of the original orange 
spots on posterior segments, but S3 anterior to the transverse carina becomes bright red. Mature individuals of both sexes show no hint of pruinosity. We do not think that the median abdominal spots are "unique and possibly primitive ... suggesting affinities with the Tetrathemistinae" (Lieftinck 1962), as numerous more advanced libellulid genera (e.g., Celithemis, Leucorrhinia, Macrodiplax) have similar spots.

\section{Pantala flavescens (Fabricius)}

Kolonia, Nett, Sokehs, Kitti, Madolenihmw, 2-90 m; 11 ð, 2 $q$. Eye colors in life orange in both sexes. This species was seldom seen during February-April but was more numerous during May-July, when it was one of the most frequently encountered odonates over roadways and open sparsely vegetated areas. It was encountered regularly but in smaller numbers again during August-September.

\section{Tholymis tillarga (Fabricius)}

Kolonia, Kitti, Madolenihmw, 3-46 m; $6 \delta, 1 q$. Eye colors in life red above, green below in male. This species was frequently seen in the lowlands, usually flying close to the ground over roadside puddles, drainage ditches, and open, sparsely vegetated seepage areas. The only female collected was a road kill. Emergence took place from a small fountain in Kolonia, where one exuvia was found on 23 December, seven on 30 December, and two on 13 January. A subsequent check revealed no additional emergence.

\section{Tramea transmarina propinqua Lieftinck}

Kolonia, Nett, Sokehs, U; 2-90 m; $3 \delta, 2$ \%. This species was observed infrequently, always in flight, and in broad open areas, including college campus grounds and grasslands.

\section{Discussion}

\section{Altitudinal and ecological distribution of Pohnpei Odonata}

The present field work found all the species known from previous publications and an additional undescribed species of Teinobasis. Table 3 shows the known altitudinal distribution of Pohnpei Odonata species, based on our collections. During this study, anisopterans were most numerous in the lowlands (Fig. 5), in open exposed areas including roadways, grassy fields, fern brakes, river banks, gardens, vacant lots, and groomed lawns. They were less abundant in the uplands, occurring mainly in patches of grasslands, thickets, and recently cut forest, but were absent from under the forest canopy. The five widespread Pacific species - Anax guttatus, Diplacodes bipunctata, Pantala flavescens, Tholymis tillarga, Tramea transmarina - may all be characteristic of more disturbed lowland habitats such as temporary ponds and even artificial water bodies. Ischnura aurora, also a widespread Pacific species, was the only zygopteran encountered in open lowland habitats and presumably coexists with the large anisopterans. No odonates were encountered in Pohnpei's extensive $\left(55 \mathrm{~km}^{2}\right)$ mangrove forest.

The habitat preferences of the three endemic anisopterans - Hemicordulia haluco, Agrionoptera sanguinolenta, Pacificothemis esakii - are unknown, although none of 
Table 3. Altitudinal distribution of Pohnpei Odonata; elevation range in $\mathrm{m}_{2}$

\begin{tabular}{lrrrrrrrr}
\hline & $0-$ & $101-$ & $201-$ & $301-$ & $401-$ & $501-$ & $601-$ & $>$ \\
& 100 & 200 & 300 & 400 & 500 & 600 & 700 & 700 \\
\hline Ischnura aurora & 21 & - & - & - & - & - & - & - \\
Teinobasis aerides & - & - & 1 & - & 2 & 1 & 4 & 7 \\
$T$. ariel & 2 & 6 & 27 & 9 & 16 & 23 & 18 & 15 \\
$T$. budeni & 3 & 1 & 6 & - & 1 & - & - & - \\
$T$. fortis & 15 & 51 & 30 & 7 & 7 & 19 & 4 & - \\
$T$. nigrolutea & - & 3 & 1 & - & 1 & 1 & 3 & - \\
$T$. ponapensis & - & - & - & - & - & - & 3 & - \\
Anax guttatus & 4 & - & - & - & - & - & - & - \\
Hemicordulia haluco & 29 & 2 & 1 & - & 5 & - & 10 & 1 \\
Agrionoptera sanguinolenta & 15 & 2 & - & - & 1 & - & 2 & - \\
Diplacodes bipunctata & 31 & - & 1 & - & 2 & - & - & - \\
Pacificothemis esakii & 1 & - & 3 & 1 & 1 & - & 3 & - \\
Pantala flavescens & 13 & - & - & - & - & - & - & - \\
Tholymis tillarga & 7 & - & - & - & - & - & - & - \\
Tramea transmarina & 5 & - & - & - & - & - & - & - \\
Total specimens & 146 & 65 & 70 & 17 & 36 & 44 & 47 & 23 \\
& & & & & & & & \\
\hline
\end{tabular}

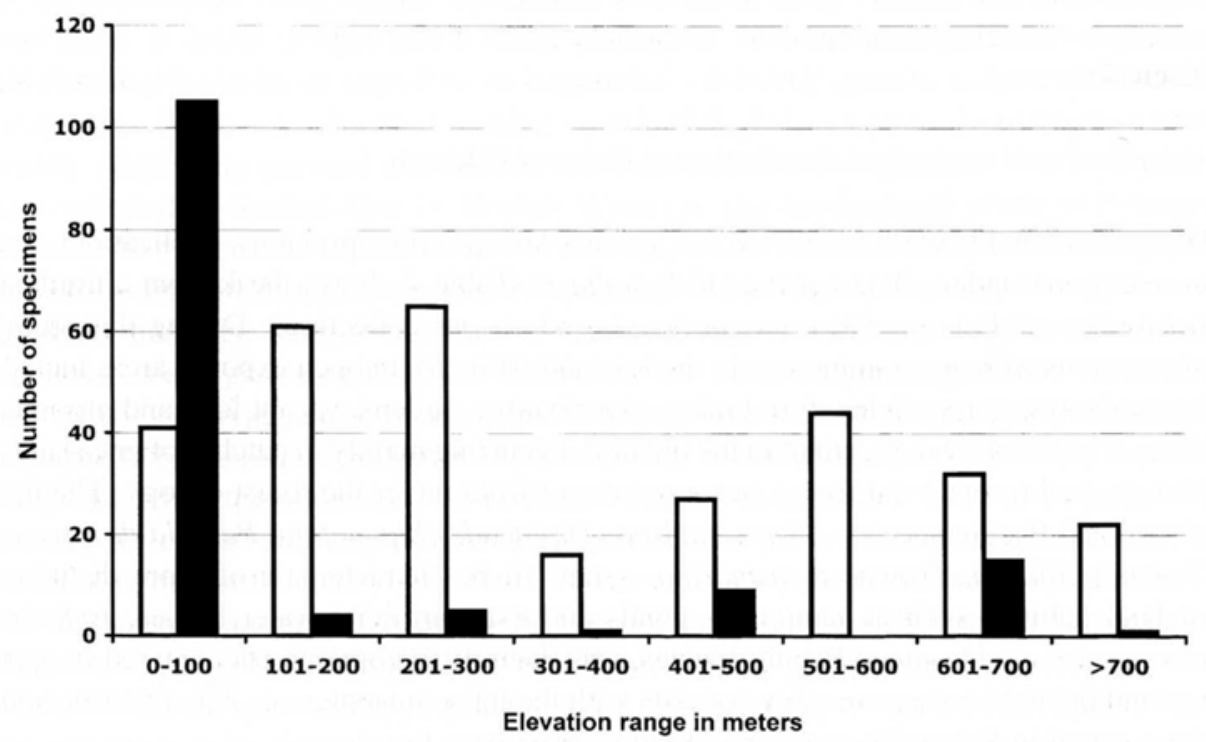

Figure 5. Altitudinal distribution of Odonata suborders on Pohnpei. White bars: Zygoptera; black bars: Anisoptera. 
them was obviously on territory or in sexual patrol flight over the island's many streams. Perhaps they breed in natural lentic habitats such as marshes, although there is some evidence that $P$. esakii may use streams. All are more common in the lowlands than the highlands, but all were collected at higher elevations, $H$. haluco with some frequency. Although quantitative data are lacking, incidental observations suggest that population densities of $H$. haluco in open sun-exposed areas in the highlands probably are at least as great as those in comparable habitats in the lowlands.

The endemic zygopterans are most numerous in the upland forest understory, being especially abundant along fast-flowing rocky streams (Teinobasis fortis and T. ariel) and associated with high-elevation marshes and with wet seepage areas where the sedge Mapania pacifica is the main ground cover (T. ariel and T. aerides). Of the rarer species, it appears that $T$. ponapensis and $T$. budeni breed in streams (the former at higher elevation than the latter), and $T$. nigrolutea probably in phytotelmata.

Odonate larvae were not found during benthic sampling in the fairly swift-flowing rocky reaches of the Nanpil-Kiepw River drainage below $100 \mathrm{~m}$ (Maciolek \& Ford 1987).

\section{Size variation with elevation}

In all three species for which sufficient material is available - T. ariel, T. fortis, $H$. haluco -, there is a slight but clear tendency for individuals from higher elevations to be larger than those in the lowlands (Fig. 6). Considering the relatively narrow altitudinal range of the island, this is striking. A variety of zygopteran species collected over a range of altitudes in Mexico and Costa Rica showed the same trend (D.R. Paulson unpubl.), which is likely related to the lower water temperature of higher elevations. Lower temperatures have been shown to cause a longer larval development time with more growth between subsequent larval instars in zygopterans (Pickup \& Thompson 1990). However, Corbet (1999: 624) listed studies that showed adult odonates being both larger and smaller at higher elevations.

\section{Seasonality of Pohnpei Odonata}

Temperature is uniform throughout the year on Pohnpei, and precipitation is moderate to great in all months, so seasonality in the odonate fauna was not expected. Indeed, many species were taken throughout the year (Table 1). The totals are higher from June to January mostly because those months represent the highest collecting effort. Four species $-I$. aurora, $P$. flavescens, $T$. tillarga, and $T$. transmarina - were collected only between June and November. The three anisopterans species appeared to be more common during that period, but individuals were seen during other months.

Emergence was not frequently documented, but teneral Teinobasis were collected in June (1 species), July (1), August (1), September (4), October (1), November (2), and January (1); exuviae of $D$. bipunctata in December; tenerals of $P$. esakii in August, November, and January; and exuviae of T. tillarga in December and January. So little collecting was done from February through May that it is not surprising that no emergence was documented during that period, but immature $H$. haluco were collected in April. 

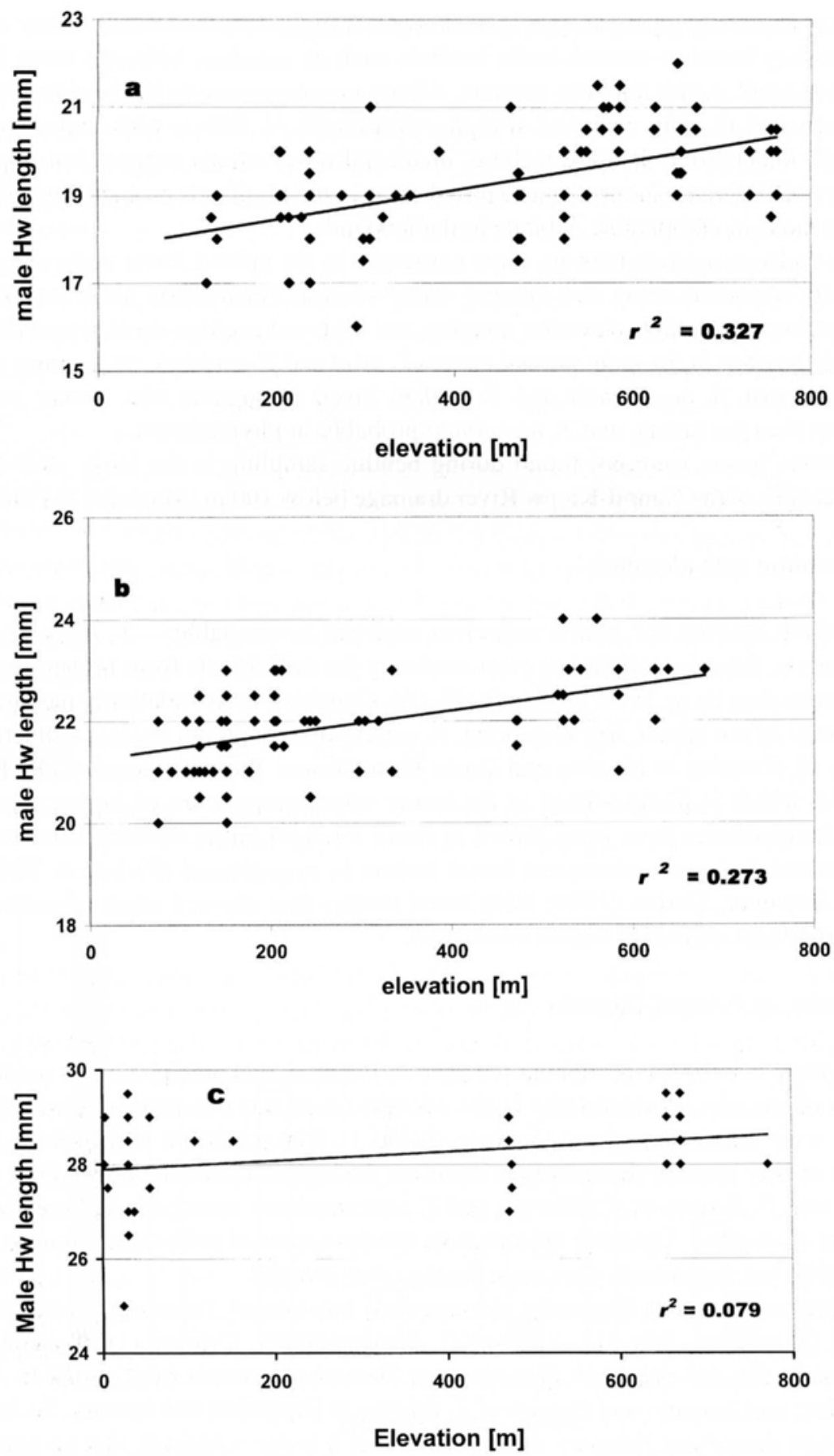

Figure 6. Size variation with elevation in some Pohnpei Odonata - (a) Teinobasis ariel; (b) T. fortis; (c) Hemicordulia haluco. 


\section{Caroline Islands biodiversity and biogeography}

The Caroline Islands are laid out in a long (approximately 2,500 km) east-west line not far north of the Equator. The westernmost, Palau, is closest to the larger land masses of the Indo-Australian archipelago and potential source areas in New Guinea, the Bismarck Archipelago, the Solomon Islands, and the Philippines. The only islands to the east are the Marshalls and Kiribati (formerly Gilbert Islands), with limited odonate faunas and no endemic species (Lieftinck 1962).

The theory of island biogeography (MacArthur \& Wilson 1967) allows us to make predictions about the diversity of species across the Micronesian archipelago. With eastward progression (moving farther from source areas), it would be predicted that species diversity would diminish. For the most part, based on presently known distributions, this in fact is the case (Table 4). Palau, the westernmost island group, indeed has the most species, Yap has fewer, and Chuuk and Kosrae have the lowest diversity. The only discrepancy is caused by Pohnpei, well to the east, which has a fauna almost as large as that of Palau and considerably larger than the islands on either side of it.

The species richness of these islands is most readily explained by island area (Fig. 7). The two largest islands, Palau and Pohnpei, support the most species, although they are rather different in physiognomy, Palau being relatively flat and Pohnpei quite mountainous, with different habitats along an elevation gradient. From its size and elevation and its placement in Figure 7, we predict that Kosrae supports more than the seven species now known to occur there (Lieftinck 1962), although it is in fact the most isolated island of the group. Both Yap and Chuuk consist of mini-archipelagos of much smaller islands, and it is not surprising that they support a low diversity of species; yet twice as many species are known from Yap, nearer source areas, than Chuuk.

\section{Intra-island speciation}

Pohnpei is unique among the Caroline Islands in having six sympatric species of a single genus, Teinobasis. Although they fall into two groups based on coloration, the species all seem closely related, with surprisingly little differences in the male terminal appendages. No other island of the group has more than one Teinobasis, and Palau - with two species of Ischnura - is the only other island with any genus represented by more than one species. The six closely related and apparently autochthonous Teinobasis species on Pohnpei clearly form a clade and do not seem particularly close to any of the other species of the genus, certainly not the other Micronesian forms ( $T$. carolinensis on Chuuk and T. palauensis on Palau). Unlike Fiji and the Hawaiian Islands, with their species assemblages of Nesobasis/Melanesobasis and Megalagrion, respectively, Pohnpei does not consist of a substantial archipelago with abundant opportunities for geographic isolation that typically precedes speciation. For example, species of picture-winged Drosophila show a clear pattern of allopatric speciation in the Hawaiian islands (Kaneshiro et al. 1995). Paulay (1994) wrote that intra-island speciation on oceanic islands had often occurred in flightless insects and land snails, but Teinobasis is in neither of these categories.

Pohnpei is smaller than other islands that present good examples of intra-island speciation. For example, there are 11 species of closely related Prognathogryllus crickets in 
Table 4. Distribution of Caroline Islands Odonata.

\begin{tabular}{lllllll}
\hline & Palau & Yap Chuuk & & & & \\
\hline
\end{tabular}

\section{Platycnemididae}

Drepanosticta palauensis Lieftinck, 1962

\section{Coenagrionidae}

Agriocnemis femina femina (Brauer, 1868)

Ischnura aurora (Brauer, 1865)

I. heterosticta (Burmeister, 1839)

Pseudagrion palauense Lieftinck, 1962

Teinobasis aerides Lieftinck, 1962

$T$. ariel Lieftinck, 1962

T. budeni Paulson, 2003

T. carolinensis Lieftinck, 1962

T. fortis Lieftinck, 1962

T. nigrolutea Lieftinck, 1962

T. palauensis Lieftinck, 1962

T. ponapensis Lieftinck, 1962

$\begin{array}{ccccr}X & X & - & - & - \\ X & X & X & X & X \\ X & - & - & - & - \\ X & - & - & - & - \\ - & - & - & X & - \\ - & - & - & X & - \\ - & - & - & X & - \\ - & - & X & - & - \\ - & - & - & X & - \\ X & - & - & X & - \\ - & - & - & X & -\end{array}$

\section{Aeshnidae}

Anaciaeschna jaspidea (Burmeister, 1839)

Anax guttatus (Burmeister, 1839)

\section{Corduliidae}

Hemicordulia erico Asahina, 1940

H. haluco Asahina, 1940

H. lulico Asahina, 1940

\section{Libellulidae}

Agrionoptera cardinalis Lieftinck, 1962

A. insignis yapensis Lieftinck, 1962

A. sanguinolenta sanguinolenta Lieftinck, 1962

A. sanguinolenta pusilla Lieftinck, 1962

Diplacodes bipunctata (Brauer, 1865)

Macrodiplax cora (Brauer, 1867)

Neurothemis terminata Ris, 1911

Pacificothemis esakii Asahina, 1940

Pantala flavescens (Fabricius, 1798)

Rhyothemis phyllis vitellina Brauer, 1868

Tholymis tillarga (Fabricius, 1798)

Tramea loewii Brauer, 1866

T. transmarina euryale Selys, 1876

-
-
X

X

- $\quad-$

$\mathrm{X}$

$-$

X

X

$\mathrm{X}$

$\mathrm{X}$

\section{$-$}

$x$

$\mathrm{X} \quad \mathrm{X}$

- $\quad-$

X X

$\mathrm{X} X$

$\mathrm{X} X$

X

X X


Table 4. Continued.

\begin{tabular}{lccccc}
\hline & Palau & Yap & Chuuk & Pohnpei & Kosrae \\
\hline Macrodiplax cora (Brauer, 1867) & $\mathrm{X}$ & $\mathrm{X}$ & - & - & - \\
Neurothemis terminata Ris, 1911 & $\mathrm{X}$ & $\mathrm{X}$ & - & - & - \\
Pacificothemis esakii Asahina, 1940 & - & - & - & $\mathrm{X}$ & - \\
Pantala flavescens (Fabricius, 1798) & $\mathrm{X}$ & $\mathrm{X}$ & - & $\mathrm{X}$ & $\mathrm{X}$ \\
Rhyothemis phyllis vitellina Brauer, 1868 & $\mathrm{X}$ & $\mathrm{X}$ & - & - & - \\
Tholymis tillarga (Fabricius, 1798) & $\mathrm{X}$ & $\mathrm{X}$ & $\mathrm{X}$ & $\mathrm{X}$ & $\mathrm{X}$ \\
Tramea loewii Brauer, 1866 & - & $\mathrm{X}$ & - & - & - \\
T. transmarina euryale Selys, 1876 & $\mathrm{X}$ & $\mathrm{X}$ & - & - & - \\
T. transmarina propinqua Lieftinck, 1942 & - & - & $\mathrm{X}$ & $\mathrm{X}$ & $\mathrm{X}$ \\
Zyxomma petiolatum Rambur, 1842 & $\mathrm{X}$ & - & - & - & - \\
\hline Total species & 18 & 13 & 6 & 15 & 7 \\
\hline
\end{tabular}

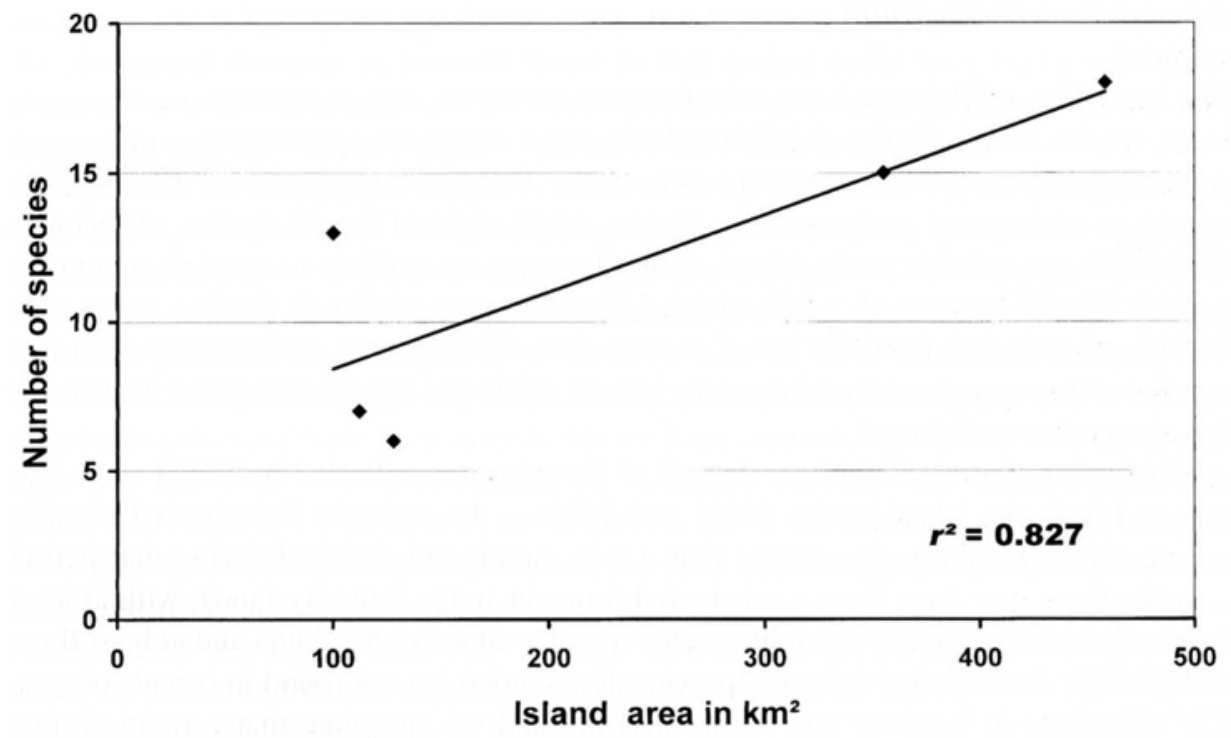

Figure 7. Island area and species richness of Caroline Islands Odonata. 
four clades that occur on Kauai (Shaw 1995). There are also 13 species of Megalagrion, ten of them endemic (Polhemus \& Asquith 1996; Daigle 1997), but the phylogeny of that genus has not been established, so intra- and inter-island speciation cannot be compared. Furthermore, Kauai is four times the size of Pohnpei and has twice the altitudinal range, with more opportunity for within-island geographic isolation. Viti Levu, Fiji, supports at least 24 closely related zygopterans of the genera Nesobasis and Melanesobasis (Donnelly 1984, 1990), but its area is 31 times that of Pohnpei.

Five genera of phytophagous Hawaiian Hemiptera were analyzed by Asquith (1995), and speciation events were thought to have taken place sympatrically (but typically on different host plants) 54 times, allopatrically on the same island 15 times, and on different islands 75 times. Speciation by switching to different host plants was considered the mode in one genus but not in the other four (Asquith 1995). Odonata, being generalist predators, are not presented with the option of sympatric speciation by switching host plants, and allopatric speciation is the only model tenable for this group. The six Pohnpei species had a very small area in which to undergo the isolation considered necessary for allopatric speciation (although the island was somewhat larger and higher earlier in its history, Spengler 1990).

Island age is also significant in diversity. Kauai has by far the most endemic zygopterans of the Hawaiian Islands, and it is the oldest large island in the chain (Polhemus \& Asquith 1996). Kauai and Pohnpei are both hot-spot islands that emerged about 5 million years ago (Keating et al. 1984; Carson \& Clague 1995). We know of no other small, isolated island with such a striking radiation of Odonata species.

\section{Comparison with other taxa}

The butterflies of Pohnpei have recently been surveyed, and 14 species are known to occur on the island (Buden \& Miller 2003). With about the same number of species, the situation is very different from that of the Odonata. Every one of the butterfly species is widespread in the western Pacific, while eight of the 15 species of Odonata in Pohnpei are endemic to the island. Butterflies may be unlikely to speciate on remote oceanic islands because of a lack of host-plant diversity (Adler \& Dudley 1994). The 14 butterflies known from the island are members of 12 genera, and no more than two species of any one genus coexist on the island, while the zygopteran genus Teinobasis has six species on Pohnpei.

Of further contrast is the fact that all of the odonates collected by DWB were also reported from the island in the 1940s and 1950s - the endemic Teinobasis budeni is presumably sufficiently uncommon that it was merely not detected during that period -, while there may have been a substantial turnover in the butterfly fauna, with at least four and possibly as many as eight species recently added to the fauna and at least three and possibly four species that were previously recorded but not found in recent surveys. The difference in turnover rate seems striking, and we speculate that a rapid change in host-plant abundance could be responsible for the rapid turnover in butterflies, while odonate populations should remain stable as long as appropriate aquatic habitats were present. 
However, the lack of endemism in Pohnpei butterflies indicates a great dispersal ability. This would increase immigration rates to the island, possibly resulting in competitive exclusion, especially because many butterflies are host-plant specialists, and two species might compete for limited host plants. Odonates are typically generalist carnivores, and at this time we know little about the ecological relationships of the Pohnpei species, although the six Teinobasis species may occupy at least three quite distinct habitats.

Lizard populations recently surveyed on Pohnpei (Buden 2000) furnish another group for comparison. Of 15 native lizard species known to occur on Pohnpei, only one is endemic. This group, which seems no more vagile than the Odonata, is also made up primarily of widespread species. Bauer (1989) emphasized the point that the "weedy" life history of highly vagile species, such as the geckos and skinks on Pacific islands, makes it unlikely for them to speciate as they reach new islands. The Teinobasis species flock on Pohnpei seems to furnish an example of a species with only moderate dispersal abilities that somehow reached a small, distant island and underwent a flurry of speciation events.

\section{Conservation issues with Pohnpei Odonata}

Lieftinck's (1962) collections can be considered a report on the status of Pohnpei Odonata a half-century ago. DWB found all the species reported by Lieftinck in at least comparable numbers, with one possible exception, $T$. nigrolutea. With the substantial field work of the recent survey, much greater numbers of all Teinobasis species were collected than were examined by Lieftinck, except for T. nigrolutea (11 Lieftinck, nine recent). This may indicate that the species is less common today, at least in the lowland area from which Lieftinck's specimens came. If it is indeed a phytotelmata breeder, then the substantial decrease in lowland forest in that period could have had a significant effect on its overall abundance. The larval habitats of the other species - streams and upland marshes and seepage areas - probably have been less altered.

The situation on Pohnpei contrasts with that on several other Pacific islands, where introduced predators may have had severe effects on at least lowland zygopterans. On the island of Oahu, in Hawaii, native Megalagrion damselflies have decreased greatly in the past century, the decline apparently correlated with the introduction of several species of poeciliid fishes (Englund 1999). On Upolo, Western Samoa, Donnelly (1986) was unable to find several coenagrionids known from the island and speculated that introduced crayfish might have been responsible for their absence. A poeciliid fish, Gambusia affinis, is said to have been introduced on Pohnpei (Maciolek 1984), but Maciolek \& Ford (1987) did not report it from the lower reaches of the Nanpil-Kiepw River system near Kolonia. Nelson et al. (1996) did not record G. affinis during their surveys of noninsect macrofauna in the Nanpil and Lehn Mesi rivers, and the only fishes encountered during recent surveys in headwater streams (above $200 \mathrm{~m}$ ) throughout Pohnpei were sicydiine gobies and the eel Anguilla marmorata (Buden et al. 2001). There appear to be few or no introduced predators in Pohnpei waters.

Some native fishes, however, may have a negative impact on local odonate populations, especially in the lower reaches of the rivers. Nelson et al. (1996) recorded two species of highly predatory flagfishes (Kuhlia rupestris and $K$. marginata) in the Nanpil 
and Lehn Mesi rivers, below the first waterfalls, which bar their upstream dispersal. They reported that "small gobies and particularly the palaemonid shrimps (Macrobrachium spp.) and atyid shrimps are in much greater abundances in the upper regions where there are no Kuhlia present... [that] when Macrobrachium are found in areas with Kuhlia, they are usually large and sequestered... [and that] young atyid shrimps are found in the lower reaches, but these are usually buried in the substrate." They concluded that "predation by flagtails is likely to have a major influence on the communities of fishes and invertebrates in the freshwater streams of Micronesia."

Pohnpei Odonata may be more seriously threatened by the continued clearing of rain forest, with increasing encroachment on the upper slopes. Effects of clearing the forest cover can be severe on stream ecosystems, and conservation efforts in Pohnpei should be focused on preserving the still luxuriant forests.

\section{References}

Adler, G.H. \& R.T. Dudley, 1994. Butterfly biogeography and endemism on tropical Pacific islands. Biological Journal of the Linnaean Society 51: 151-162.

Asahina, S., 1940. Odonata-Anisoptera of Micronesia. Tenthredo 3: 1-23.

Asquith, A., 1995. Evolution of Sarona (Heteroptera, Miridae). In: Wagner, W.L. \& V.A. Funk (eds) "Hawaiian biogeography: evolution on a hot spot archipelago", Smithsonian Institution Press, Washington, pp. 90-120.

Bauer, A.M., 1989. Reptiles and the biogeographic interpretation of New Caledonia. Tuatara 30: 39-50.

Bryan, E.H., Jr., 1971. Guide to place names in the Trust Territory of the Pacific Islands. Pacific Science Information Center, B.P. Bishop Museum, Honolulu.

Buden, D.W., 2000. The reptiles of Pohnpei, Federated States of Micronesia. Micronesica 32: 155-180.

Buden, D.W. \& J.Y. Miller, 2003. The butterflies of Pohnpei, Eastern Caroline Islands, Micronesia. Pacific Science 57 , in press.

Buden, D.W., D.B. Lynch \& R.E. Watson, 2001. The gobiid fishes (Teleostei: Gobioidei: Sicydiinae) of the headwater streams of Pohnpei, Eastern Caroline Islands, Federated States of Micronesia. Micronesica 34: $1-10$.

Carson, H.L. \& D.A. Clague, 1995. Geology and biogeography of the Hawaiian Islands. In: Wagner, W.L. \& V.A. Funk (eds) "Hawaiian biogeography: evolution on a hot spot archipelago", Smithsonian Institution Press, Washington, pp. 14-29.

Corbet, P.S., 1999. Dragonflies: behavior and ecology of Odonata. Cornell University Press, Ithaca, NY.

Daigle, J.J., 1997. Megalagrion mauka spec. nov. from Kauai, Hawaii (Zygoptera: Coenagrionidae). Odonatologica 26: 65-69.

Donnelly, T.W., 1984. Melanesobasis gen. nov., a new genus of Fijian damselflies: a possible link between the platycnemidid Lieftinckia and certain coenagrionids (Zygoptera). Odonatologica 13: 89-105.

Donnelly, T.W., 1986. Preliminary report on Odonata collected in Samoa, 1985. Notulae Odonatologicae 2: 109-112.

Donnelly, T.W., 1990. The Fijian genus Nesobasis. Part 1: species of Viti Levu, Ovalau, and Kadavu (Odonata: Coenagrionidae). New Zealand Journal of Zoology 17: 87-117.

Englund, R., 1999. The impacts of introduced poeciliid fish and Odonata on the endemic Megalagrion damselflies of Oahu Island, Hawaii. Journal of Insect Conservation 3: 225-243.

Gressitt, J.L., 1954. Insects of Micronesia, introduction. Insects of Micronesia 1: 1-257. 
Kaneshiro, K.Y., R.G. Gillespie \& H.L. Carson, 1995. Chromosomes and male genitalia of Hawaiian Drosophila. In: Wagner, W.L. \& V.A. Funk (eds) "Hawaiian biogeography: evolution on a hot spot archipelago", Smithsonian Institution Press, Washington, pp. 57-71.

Keating, B.H., D.P. Mattey, C.E. Helsley, J.J. Naughton, D. Epp \& D. Lazarewicz, 1984. Evidence for a hot spot origin of the Caroline Islands. Journal of Geophysical Research 89: 9937-9948.

Laird, W.E., 1982. Soil survey of island of Ponape, Federated States of Micronesia. U.S. Department of Agriculture, Soil Conservation Service.

Lieftinck, M.A., 1962. Insects of Micronesia. Odonata. Insects of Micronesia 5: 1-95.

MacArthur, R.H. \& E.O. Wilson, 1967. The theory of island biogeography. Princeton University Press, Princeton.

Maciolek, J.A., 1984. Exotic fishes in Hawaii and other islands of Oceania. In: Courtenay, W.R., Jr. \& J.R. Stauffer, Jr. (eds) "Distribution, biology, and management of exotic fishes", Johns Hopkins University Press, Baltimore, pp. 131-161.

Maciolek, J.A. \& J.I. Ford, 1987. Macrofauna and environment of the Nanpil-Kiepw River, Ponape, eastern Caroline Islands. Bulletin of Marine Science 41: 623-632.

MacLean, C.D., T.G. Cole, C.D. Whitesell, M.V. Falanruw \& A.H. Ambacher, 1986. Vegetation survey of Pohnpei, Federated States of Micronesia. Resource Bulletin PSW-18. Pacific Southwest Forest and Range Experiment Station. Forest Service, U.S. Department of Agriculture.

Merlin, M., D. Jano, B. Raynor, T. Keene, J. Juvik \& B. Sebastian, 1992. Tuhke en Pohnpei: plants of Pohnpei. East-West Center, Program on Environment, Honolulu.

Needham, J.G. \& M.K. Gyger, 1939. The Odonata of the Philippines, II. Suborder Zygoptera. Philippine Journal of Science 70: 239-314.

Nelson, S.G., F.A. Camacho, J.E. Parham, R.B. Tibbats, T. Leberer \& B.D. Smith, 1996. Surveys of the macrofauna of the Nanpil-Kiepw and Lehn Mesi rivers of Pohnpei. University of Guam Marine Laboratory Technical Report No 103.

Paulay, G., 1994. Biodiversity on oceanic islands: its origin and extinction. American Zoologist 34: 134-144.

Paulson, D.R., 2003. Teinobasis budeni sp. nov. from Pohnpei, Eastern Caroline Islands, Micronesia (Odonata: Coenagrionidae). International Journal of Odonatology 6: 33-37.

Pickup, J. \& D.J. Thompson. 1990. The effects of temperature and prey density on the development rates and growth of damselfy larvae (Odonata: Zygoptera). Ecological Entomology 15: 187-200.

Polhemus, D. \& A. Asquith, 1996. Hawaiian damselflies: a field identification guide. Bishop Museum Press, Honolulu.

Polhemus, D., A. Asquith \& S. Miller, 2000. A new species of Ischnura from Rota (Odonata: Coenagrionidae), and a discussion of zygopteran zoogeography in the insular Tropical Pacific. Bishop Museum, Occasional Paper no. 62: 1-12.

Raynor, B., 1993. Montane cloud forests in Micronesia: status and future management. In: Hamilton, L.S., J.O. Juvik \& F.N. Scatena (eds) "Tropical montane cloud forests", Proceedings of an International Symposium. East-West Center Program on Environment, Honolulu, pp. 172-182.

Rowe, R.J., 1978. Ischnura aurora (Brauer), a dragonfly with unusual mating behaviour (Zygoptera: Coenagrionidae). Odonatologica 7: 375-383.

Shaw, K.L., 1995. Biogeographic patterns of two independent Hawaiian cricket radiations (Laupala and Prognathogryllus). In: Wagner, W.L. \& V.A. Funk (eds) "Hawaiian biogeography: evolution on a hot spot archipelago", Smithsonian Institution Press, Washington, pp. 39-56.

Spengler, S.R., 1990. Geology and hydrogeology of the island of Pohnpei, Federated States of Micronesia. Dissertation, University of Hawaii. 
Trustrum, N.A., 1996. Pohnpei's watershed spatial plan and management guidelines (Consultant's report prepared for the Asian Development Bank, T.A. no. FSM-1925; Watershed Management and Environment). Landcare Research, New Zealand, Ltd.

U.S. Army Corps of Engineers, 1986. Pohnpei coastal resource inventory. U.S. Army Engineers Pacific Ocean Division, Fort Shafter, Hawaii.

U.S. Geological Survey, 1983. Topographic map of the island of Ponape (2 sheets). Scale 1:25,000. U.S. Geological Survey, Reston, Virginia. 